\title{
Katell Berthelot, In Search of the Promised Land? The Hasmonean Dynasty Between Biblical Models and Hellenistic Diplomacy (Journal of Ancient Judaism. Supplements - 24), Vandenhoeck \& Ruprecht, Göttingen-Bristol, CT 2018, 494 pp., 2 maps, ISSN 2198-1361; ISBN 978-3-525-55252-0
}

Many generations of researchers have tended to focus more on disputes over the causes and events of the Maccabean Revolt than on Hasmonean history. Only recently has a distinct change in this approach been discernible. On the one hand, this was caused by intensive studies of 1 and 2 Maccabees and the Dead Sea Scrolls as well as interest in the works of Josephus. On the other, it resulted from the archaeological discoveries made over the last 30 years in Israel. Both these factors have added appreciably to what we know both about various aspects of Hasmonean rule and the associated internal and externa circumstances and about the achievements of each of the rulers of the dynasty. It is notable, however, that the discussions among researchers on the history of Judaea under Hasmonean rule and its results always include questions concerning the nature of their expansion policy. The most common ones are those about its ideological aspect and the forced Judaization of the population of the conquered territories. The problem is the lack of consensus among researchers regarding these issues. The opinions they express are frequently at odds. Accepting one or another is not easy, however, without a critique of the positions presented. Such an attempt - successful, we might add - has been made by Katell Berthelot in her imposing volume In Search of the Promised Land? The Hasmonean Dynasty between Biblical Models and Hellenistic Diplomacy. Berthelot defines the main goals of her studies as follows: "both to contribute to the history of the Hasmonean period and to present a wider historiographical, or even hermeneutic, argument. I wish to show how certain readings of the sources have led to the construction of often superficially self-evident but deeply misguided historiographical paradigms" (p. 18).

The book's title leaves no doubt that the author's main subject of interest is exclusively the expansion policy pursued by the rulers of Judaea in the period from 143 to 76 $\mathrm{BCE}$. The presence of the question mark in the title makes it clear that it is the ideological aspects of this policy that are her main focus.

The book is composed of five main parts, including the Introduction (The Historiography of the Hasmonean Period: The Influence of Biblical Models and of Modern Debates on the Creation of a Jewish State (pp. 15-64)), which introduces the reader to the research methodology the author employs, the notions she uses and the difficulties that using the categories "religion" and "politics" causes in the context of research on the 
Hasmonean era. In this part of the book, the author also conducts an extensive review of the major positions that have emerged over the course of more than a century and a half of historiography concerning the Hasmoneans (cf. pp. 19-51). She also notes that the concept of "promised land," a common theme in the context of the expansion policy of the rulers of Judaea, is used somewhat arbitrarily, often without clearly specifying its geographical dimension (pp. 52-57). Berthelot then, in Part I: Did the Hasmoneans Seek to Reconquer the Promised Land or Restore Judea? The Account of the Hasmonean Wars in 1 Maccabees (pp. 65-212), presents an analysis of the information in 1 Macc on Hasmonean expansion, criticism of the findings and opinions given in historiography, and her own conclusions. The author is interested in a wide range of issues, in most cases concerning the connections between biblical tradition and the realities of the time. She also devotes significant space to the question of the relations between Jews and other ethnic groups (pp. 118-152) and the practice of religious purification of the conquered territories attributed to Simon (pp. 153-161). One commonly quoted argument in favour of the interpretation of the Hasmoneans' expansion as an aspiration to regain the areas constituting the biblical "promised land" is the expression "the inheritance of our fathers" (1 Macc 15: 33). According to the author of 1 Macc, this was used by Simon in a response addressed to Athenobius, an envoy of Antiochus VII, in which he rejected the Syrian king's accusations that the Jews had conquered the lands belonging to Seleucids (cf. 1 Macc 15: 28-36). According to Berthelot, following a thorough analysis of the content of this concept and the way it is used in the texts of other Jewish authors, this argument is groundless. She shows that the term was used exclusively to refer to Judaea (pp. 161-162, esp. 212). There is also no doubt that the author of 1 Macc subordinated the image of the activity of the Hasmoneans modelled on biblical tradition to the goals of their political propaganda. ${ }^{1}$

In Part II: The Era of the Conquests: Rise and Fall of the Hasmonean State (pp. 213340), the author analyses sources concerning Judaea's territorial expansion under the rule of John Hyrcanus, Aristobulus I and Alexander Jannaeus. The most complete picture of this expansion is presented only in the works of Josephus, but certain echoes of the Judaean rulers' activity were also preserved in other authors' works. Their references are useful in comparing the contents of all sources. Berthelot is interested in the motifs of the actions undertaken by the various rulers, but the most space in her reflections is reserved for the topic of forced Judaisation of the Idumeans, Itureans and Greek residents of the cities of the Decapolis (pp. 283-324). Another problem she considers is the issues of the Hasmoneans' use of mercenaries and their reasons for needing them (pp. 324-334). Regarding the motives that guided the rulers of Judaea in their expansion, the author attributes it to the weakness of the Syrian rulers, not aspirations to regain control over the "promised land" (p. 283). The destruction of the places of foreign cults that accompanied this expansion was not its objective, but rather a consequence (p. 283). The author's conclusions with regard to the goals of forced Judaization partly coincide with the view expressed previously - that it was a tool of religious integration of society - but also add new elements to this perspective. She rightly emphasises the variety of the Hasmoneans'

${ }^{1}$ Cf. p. 212: “... the key function of these biblical model was the political legitimation of the Hasmonean dynasty, not the justification of a programme of reconquest based on the biblical descriptions of the borders of the promised land." 
positions in efforts to subject specific ethnic groups to Jewish religious laws. This allowed them to maintain their own distinctness. Although they stripped these groups of some of the rights they had enjoyed hitherto, primarily the ban on continuing their own religious practices, they did not have the absolute goal of assimilation. They therefore exhibited a position closer to the practices of the Hellenistic world than biblical traditions, imitation of which was ascribed to them by the author of 1 Macc (cf. pp. 298-324, esp. 321-324). The connections between the rulers of Judaea and this world were manifested in the enlisting of mercenaries, whom they needed in order to preserve their own political position, especially in the light of the intensifying opposition to their rule.

Certainly the most interesting section of the book is Part III: Polemic, Memory, Forgetting (pp. 342-426) concerning the attitude of authors of the contemporary sources to the Hasmonean expansion policy and evaluation of their accomplishments in rabbinical tradition. It has long been known that some of the Dead Sea Scrolls from the time of the Hasmoneans contain harsh criticism levelled at them. The main targets are John Hyrcanus and Alexander Jannaeus, as a result of their hostile actions towards the Qumran community as well as various negative phenomena present in their rule. However, analysis and interpretation of these allusions and mentions in the Qumran scrolls do not always provide a clear-cut answer as to who was being referred to. Their very character also sometimes arouses similar doubts. As an example we might take text 4Q448, which has long been controversial among scholars. Some see it as a prayer for Alexander Jannaeus, which, they argue, makes it unique compared to other documents from Qumran. Others view this interpretation as incorrect, and see the author having rather a negative attitude towards the ruler. The reason for these differences in understanding is the document's fragmentary state of preservation. Depending on the proposed reconstruction of the damaged part of the text, crucial to deciphering its meaning, its entire tenor changes. According to Berthelot, the "prayer" is aimed against Alexander Jannaeus (pp. 375383). There is also one more text, from another socio-religious community, which is contemporary to the last Hasmoneans and at the same time very critical of them: Psalms of Solomon (pp. 390-394).

A different picture of the activity of John Hyrcanus and Alexander Jannaeus is painted in rabbinical literature, whose authors are hardly interested in their military achievements at all. The only exception is Megillat Ta'anit, which mentions only the feast days associated with the military successes of the Hasmoneans, albeit mostly those from the period of the Maccabean Revolt (pp. 396-402). The author notes that other rabbinical texts are almost completely lacking in references to the Hasmoneans' expansion policy (p. 416). What is present in these texts is criticism for the concentration of the function of high priest and political leader, which, according to their authors, should be separate (pp. 408-416). Ambivalent assessments of the Hasmoneans can be found in the Babylonian Talmud. The heroes of the Maccabean uprising receive a positive evaluation, whereas Alexander Jannaeus and his sons are roundly criticised (pp. 416-426). In the conclusion (pp. 427-433), the author sums up her quintessential arguments.

This book is a testimony to Berthelot's tremendous erudition as well as the effectiveness of her innovative research methodology as well as a critical approach to previous historiography. Her selection of subject matter is the right one in all respects, since in the discussions surrounding it, with its extremely frequent references to the policy of 
the various rulers of Judaea, the same conclusions and opinions tend to be repeated. The author's broad perspective on the aims and motives that guided the Hasmoneans in their expansion policy led her to conclusions that have previously rarely occurred in the discussion. According to the author, however, her emphasis on the pragmatic dimension of this policy, perceived from the point of view of the behaviour appropriate for rulers of the Hellenistic world, by no means excludes its religious aspects. Perhaps they would be more noticeable if we were to look at the effects of their policy on the conquered territories (I do not mean the Hasmoneans' deliberate or unwitting destruction of the places of foreign cults, but their popularisation there of miqvaot, for example) - something that is absent in this book. Although Hellenistic models are without doubt present in various fields of the Hasmoneans' domestic and foreign policy, they cannot hide the fact that distinctly religious contents are also in place. The book contains numerous new findings and interpretations, which there is no space to mention here. These are all based on meticulous analysis of the sources and supported by convincing arguments, and will certainly form a point of reference for further research, but some may also be subject to criticism. This is because for certain questions, including the one concerning identification of the areas conquered by Aristobulus I, we do not find an unambiguous - or exhaustive - answer in the book. But this is not a complaint to the author. The reason why such answers remain elusive is simply the condition of the sources, even despite their increased number. There is no doubt that Berthelot's book will hold a place in the canon of the literature on the Hasmonean era for a long time to come.

Edward Dąbrowa (Jagiellonian University in Kraków) 